\title{
OPEM
}

www.opem.org

Oriental Pharmacy and Experimental Medicine 2010 10(3), 208-213

DOI 10.3742/OPEM.2010.10.3.208

\section{Antimicrobial and lipid peroxidation inhibition activity of Oxystelma esculentum (Asclepiadaceae)}

\author{
Ashok Kumar D*, Thamil Selvan V, Prerona Saha, Aminul Islam, Upal Kanti Mazumder and \\ Malaya Gupta
}

Department of Pharmaceutical Technology, Jadavpur University, Kolkata, 700 032, India

Received for publication November 26, 2007; accepted September 7, 2010

\begin{abstract}
SUMMARY
The aerial parts of methanol extract of Oxystelma esculentum (MEOE) (Asclepiadaceae) was evaluated for in vitro lipid peroxidation and antimicrobial activity. Lipid peroxidation was assayed by the change in optical density of the various concentrations $(20-320 \mu \mathrm{g} / \mathrm{ml})$ and the percentage inhibition was estimated. Ascorbate/FeSO4-induced peroxidation was inhibited by MEOE and standard antioxidants such as BHA, BHT and the percentage inhibition of the methanol extract was increased with dose dependent manner. The $\mathrm{IC}_{50}$ value of the MEOE, BHA and BHT for lipid peroxidation was found to be $135.24 \mu \mathrm{g} / \mathrm{ml}, 25.62 \mu \mathrm{g} / \mathrm{ml}$ and $17.13 \mu \mathrm{g} / \mathrm{ml}$, respectively. The antimicrobial activity of MEOE was determined by disc diffusion method with three grampositive, five gram-negative and two fungal microorganisms. MEOE exhibited the antimicrobial activity against the tested microorganisms except Salmonella typhimurium (MTCC 98). In present study, it is concluded that MEOE has significant effect in the inhibition of lipid peroxidation and possesses good antimicrobial activity.
\end{abstract}

Key words: Oxystelma esculentum; Lipid peroxidation; Antimicrobial activity

\section{INTRODUCTION}

Infectious diseases like diarrhoea, dysentery, tuberculosis, acute respiratory tract infections, AIDS and recently SARS are global threat and their incidences are increasing significantly day by day. Although a number of chemotherapeutic agents are available in market places, the pathogenic organisms are developing resistance to these agents. So, it is important to find out safer, more effective and inexpensive chemotherapeutic agents. In recent years, multiple drug resistance has developed due

\footnotetext{
*Correspondence: Ashok kumar D, Department of Pharmaceutical technology, Jadavpur University, Kolkata, 700032 India. Tel: +919433435247; E-mail: ashokkumardurairaj@yahoo.co.in
}

to indiscriminate use of existing antimicrobial drugs in the treatment of infectious diseases. In addition to this, antibiotics are some times associated with adverse effects on the host-like hypersensitivity. Therefore the needs to develop alternative antimicrobial drugs for the treatment of infectious diseases from other sources such as plants are increasing. Natural plants of higher plants may be a new source of antimicrobial agents possibly with novel mechanisms of action (Jigna et al., 2005).

Oxystelma esculentum R. Br. (Family: Asclepiadaceae) is a perennial twining herb with milky juice. It is distributed throughout the plains, usually near water and lower hills of India, Ceylon and Java (Gamble, 1957; Chopra et al., 1958). The decoction of the plant used as gargle in aphthous ulcerations 
of mouth and in sore throat. Root considered specific for jaundice and milk sap used as a wash for ulcers (Chopra et al., 1956; Nadkarni, 1954). The plant is a diuretic, aphrodisiac, anthelmintic and bronchitis, useful in leucoderma and the fruit is expectorant, anthelmintic and the juice is used in gonorrhoea, muscle pain (Kirthikar and Basu, 1935). A cardenolide tetraglycoside, oxyline isolated from roots and polyhydroxypregnane glycosides, alpinoside A, B and C from aerial parts of the plant was reported (Srivastava et al., 1991; Hamed et al., 2004). Therefore, the aim of the present work is to evaluate the in vitro lipid peroxidation and antimicrobial potential of methanol extract of the Oxystelma esculentum on several microorganisms that are medical importance.

\section{MATERIALS AND METHODS}

\section{Plant material}

The aerial part of the plant Oxystelma esculentum was collected during November 2004 from Srirangapatnam, Near Mysore, Karnataka, India. The plant material was taxonomically identified by the Prof. Revenna, H.O.D, Department of Botany, Kuvempu First Grade Degree College, Channapatna, Karnataka, India, and the voucher specimen (No: DAKJU - 02/2005) were preserved in our departmental laboratory for future reference. The plant material were dried, powdered with a mechanical grinder and stored in an airtight container. The powdered material $(480 \mathrm{~g}$ ) was defatted with petroleum ether $\left(60-80^{\circ} \mathrm{C}\right)$ and the defatted powdered material thus obtained was further extracted with methanol for $72 \mathrm{~h}$ in a soxhlet apparatus. The solvent was removed by distillation under suction and the resulting semisolid mass was vacuum dried using rotary flash evaporator to yield $(14.60 \% \mathrm{w} / \mathrm{w})$ a solid residue. The preliminary phytochemical analysis of the petroleum ether and methanol extract were performed to identify the nature of the constituents (Kokate, 1997). The methanol extract of Oxystelma esculentum (MEOE) thus obtained was directly used in the study.

\section{Chemicals and drugs}

Thiobarbituric acid (TBA), Butylated hydroxytoluene (BHT), Butylated hydroxyanisole (BHA) from Loba Chemie Pvt Ltd, Mumbai, India. The antibiotics used in this study were tetracycline (Hindustan Antibiotics, Pimpri, India), amphotericin B (Criticare, India) obtained from the respective manufacturer.

\section{Microorganisms used}

Bacterial Strains includes Gram- positive strains such as Staphylococcus aureus (MTCC 96), Staphylococcus epidermidis (MTCC 435), Proteus vulgaris (MTCC 1429), Gram-negative strains like Escherichia coli (MTCC 433), Salmonella paratyphi A (MTCC 735), Salmonella paratyphi B (Clinical isolate), Klebsiella pneumonia (MTCC 432), Salmonella typhimurium (MTCC 98) and Fungal Strains of Candida albicans (MTCC 183), Cryptococcus neoformans (Clinical isolate) were collected from stock culture of Indian Institute of Chemical Biology, Kolkata, Central Drug Laboratory, Kolkata and Plant Pathology Laboratory, Calcutta University, Kolkata, India. The microbial strains were maintained on agar slant at $4{ }^{\circ} \mathrm{C}$ and subcultured on a fresh appropriate agar plate $24 \mathrm{~h}$ prior to antimicrobial test. For this antimicrobial evaluation, Nutrient Agar and Sabouraud Dextrose Agar were used for the activation of bacteria and fungi, respectively. Muller Hinton Agar (MHA) was used for the diffusion assays. The nutrient agar media and standard discs of $6 \mathrm{~mm}$ diameter were procured from M/S Himedia, Mumbai, India.

\section{Lipid peroxide scavenging activity}

Lipid peroxidation induced by $\mathrm{Fe}^{2+}$-ascorbate system in rat liver homogenate was determined using thiobarbituric acid reacting substances (TBARS) by the method of Ohkawa et al. (1979). The reaction mixture contained rat liver homogenate in $0.1 \mathrm{ml}$ $(25 \% \mathrm{w} / \mathrm{v})$ of Tris- $\mathrm{HCl}$ buffer $(40 \mathrm{mM}, \mathrm{pH} 7.0)$, $0.1 \mathrm{ml}$ of $\mathrm{KCl}(30 \mathrm{mM}), 0.1 \mathrm{ml}$ of ferrous iron $(0.16$ $\mathrm{mM}), 0.1 \mathrm{ml}$ of ascorbic acid $(0.06 \mathrm{mM})$, and 
different concentrations of MEOE $(20-320 \mathrm{mg} / \mathrm{ml})$ in a final volume of $0.5 \mathrm{ml}$. The reaction mixture was incubated at $37^{\circ} \mathrm{C}$ for $1 \mathrm{~h}$. After the incubation, $0.4 \mathrm{ml}$ was removed and treated with $0.2 \mathrm{ml}$ sodium dodecyl sulphate (SDS - 8.1\%), $1.5 \mathrm{ml}$ thiobarbituric acid (TBA - $0.8 \%$ ) and $1.5 \mathrm{ml}$ acetic acid ( $20 \%, \mathrm{pH} 3.5)$. The total volume was made up to $4.0 \mathrm{ml}$ by adding distilled water and then kept in a water bath at $100 \times C$ for $1 \mathrm{~h}$. After cooling, $1.0 \mathrm{ml}$ of distilled water and $5.0 \mathrm{ml}$ of n-butanol and pyridine mixture $(15: 1 \mathrm{v} / \mathrm{v})$ were added to the reaction mixture, shaken vigorously and centrifuged at $4000 \mathrm{rpm}$ for $10 \mathrm{~min}$. The butanol-pyridine layer was removed and its absorbance at $532 \mathrm{~nm}$ was measured to quantify the TBARS. The percentage inhibition of lipid peroxidation was evaluated by comparing the results of the test compounds with that of the control not treated with the extracts concentration needed for 50\% inhibition was calculated. BHA and BHT were used as standard.

\section{Evaluation of antimicrobial studies}

Preparation of sample solution

Stock solution of the MEOE at the concentration of $1,000 \mu \mathrm{g} / \mathrm{ml}$ was prepared using DMSO for the samples. DMSO was sterilized by filtration using G - 5 filter. Stock solutions were diluted by the sterile DMSO at the concentration of 100, 200, 300, 400 and $500 \mathrm{mg} / \mathrm{ml}$. The solvent DMSO was used as control.

\section{Antimicrobial assay}

Antibacterial and antifungal sensitivity tests were experimented by the disc diffusion method (National Committee for Clinical Laboratory Standards, 1997). Agar cultures of the test strains were prepared. Three to five similar colonies were selected and transferred with loop in to $5 \mathrm{ml}$ of Tryptone soya broth, a highly nutritious versatile medium, which is recommended for general laboratory purpose and used for the cultivation of aerobes and facultative anaerobes, including some fungi. The broth cultures were incubated for $24 \mathrm{~h}$ at $37^{\circ} \mathrm{C}$. The inoculum for each organism was prepared from broth cultures. The concentration of cultures was to $10^{8}$ colony-forming units $\left(1 \times 10^{8} \mathrm{cfu} / \mathrm{ml}\right)$. For the antimicrobial study, sterile impregnated discs with MEOE, at concentrations of $100-500 \mathrm{mg} / \mathrm{ml}$ was aseptically placed on the sensitivity agar plates with the help of a sterile fine pointed forceps at a suitable distance apart so that the respective disc can produce clear zones of inhibition around them. All the plates were then incubated either at $16-18 \mathrm{~h}$ at $37^{\circ} \mathrm{C}$ for bacteria and at $30^{\circ} \mathrm{C}$ for $24 \mathrm{~h}$ in case of fungi. The zone of all the doses of MEOE for various organisms was measured at the end of incubation period. The degree of sensitivity was determined by measuring the zone of growth inhibition produced by the diffusion of extract from the respective discs on agar surface around the discs. The zones showing complete inhibition was compared with reference standard drugs, tetracycline $(4 \mu \mathrm{g} / \mathrm{ml})$ and amphotericin B $(10 \mu \mathrm{g} / \mathrm{ml})$ (Ananthanarayanan and Jayaram Paniker, 1987; Pelczar et al., 1997).

\section{Statistical analysis}

All treatments were performed in triplicate and each data in the results is the mean of three tests. The statistical significance of the values was expressed as mean \pm S.E.M.

\section{RESULTS}

The present study illustrated the inhibition of lipid peroxidation and antimicrobial activities of the methanol extract of Oxystelma esculentum. Phytochemical analysis revealed the presence of triterpenoids, saponins, and gums in petroleum ether and glycosides, triterpenes, tannins, flavonoids and steroids in methanol extract.

\section{Inhibition of lipid peroxidation}

The inhibition of lipid peroxidation by MEOE and standard antioxidants such as BHA and BHT on the in vitro lipid peroxidation is summarized in Fig. 1 . The generation of lipid peroxidase by $\mathrm{Fe}^{2+}-$ 


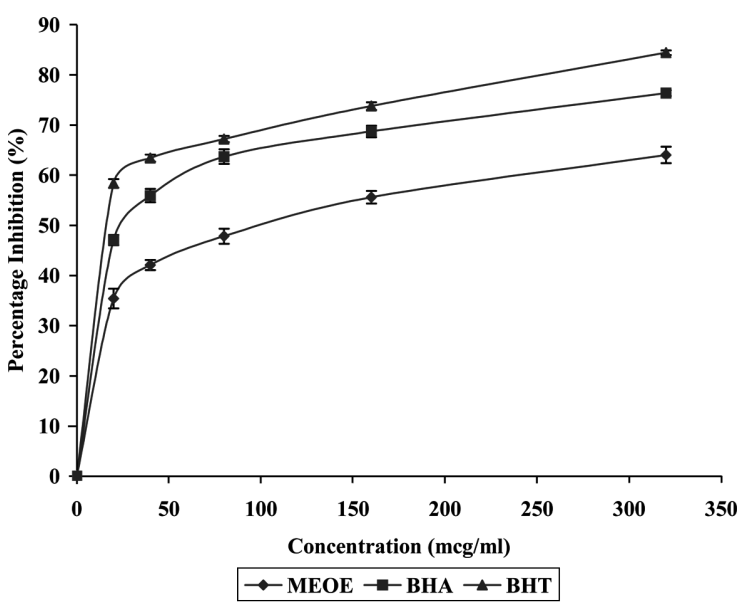

Fig. 1. Effect of MEOE on lipid peroxidation.

ascorbate in rat liver homogenate seems to be inhibited by MEOE with $\mathrm{IC}_{50}$ value of $135.24 \mu \mathrm{g} / \mathrm{ml}$. The $\mathrm{IC}_{50}$ value of BHA and BHT were $25.62 \mu \mathrm{g} / \mathrm{ml}$ and $17.13 \mu \mathrm{g} / \mathrm{ml}$ respectively.

\section{Screening of antimicrobial activity}

The antimicrobial activity of three Gram-positive organism, five Gram-negative organisms and two fungal strains were used to evaluate the possible activities of methanol extract of Oxystelma esculentum. Gram-positive bacteria of Staphylococcus epidermidis, Staphylococcus aureus and Proteus vulgaris were exhibited significant at 400 and $500 \mu \mathrm{g} / \mathrm{ml}$. Gram negative bacteria, Salmonella paratyphi A, Klebsiella pneumonia, Escherichia coli exhibited significant effect at $200-500 \mu \mathrm{g} / \mathrm{ml}, 300-500 \mu \mathrm{g} / \mathrm{ml}$ and $400-500$ $\mu \mathrm{g} / \mathrm{ml}$ respectively, in dose dependent manner. Salmonella paratyphi $B$ was effective only at $500 \mathrm{mg} / \mathrm{ml}$. Salmonella typhimurium did not show any positive result. Fungal strains of Candida albicans and Cryptococcus neoformans observed the significant activity at $500 \mu \mathrm{g} / \mathrm{ml}$.

DMSO used as control and did not show antimicrobial activity. The antimicrobial activity was compared with standard drugs, tetracycline (4 $\mu \mathrm{g} / \mathrm{ml})$ for bacteria and amphotericin B $(10 \mu \mathrm{g} / \mathrm{ml})$ used for the fungi (Table 1).

\section{DISCUSSION}

Lipid peroxidation is the oxidative deterioration of polyunsaturated lipids. Peroxidative reactions for nonbiological olefinic substances are known. The peroxidative process leads to the formation of free radical intermediates, which can lead to autocatalysis (Plaa and Witschi, 1976). Unsaturated lipids in liver tissue were very susceptible to peroxidation when they were exposed to reactive oxygen species (ROS). In the present work, the liver tissue was incubated in presence of a ROS generating system, ascorbate $/ \mathrm{FeSO}_{4}$. Lipid peroxides generated by the induction of $\mathrm{Fe}^{2+}$ / ascorbate on rat liver homogenate

Table 1. Antimicrobial activity of MEOE (as mm inhibition zone)

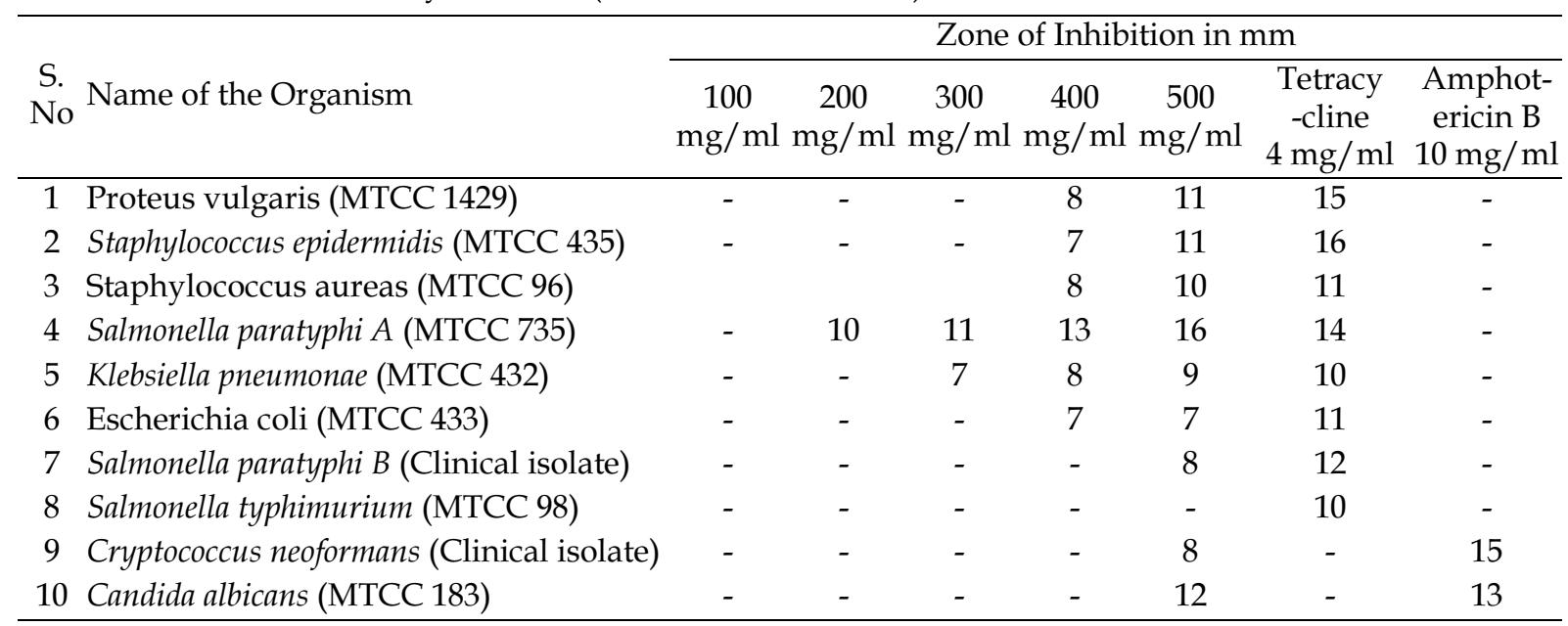


inhibited by the addition of the extract was found. MEOE exhibited the significant effect at quantities of $20-320 \mu \mathrm{g} / \mathrm{ml}$ inhibited the formation of lipid peroxides in a concentration dependent manner.

In vitro antimicrobial activity of methanol extracts could reveal the presence or absence of inhibition by measuring the zone diameters from different bacterial and fungal organisms. Disc diffusion methods are extensively used to evaluate the antibacterial activity of natural substances and plant extracts (Bartner et al., 1994).

The antimicrobial activity of the diterpenoids and flavones is probably due to the membrane disruption by terpenes (Urzua et al., 1998; Cowan, 1999) and their activity might be due to their ability to form complex with extracellular, soluble proteins and to complex with bacterial cell walls (Cowan, 1999) and disrupt microbial membranes (Tsuchiya et al., 1996). The antifungal activity might be due to binding with the sterol of fungi and form a pore or channel, which leads to increase in permeation of cell membrane which in turn increase the leakage of variety of small molecules. Otherwise it may induce the oxidative damage in the fungi cell. The possible way of antimicrobial activity of plant extract may be by inhibiting the cell wall synthesis, metabolism, protein synthesis and DNA synthesis in microorganism (Goodman and Gillman, 2001). MEOE exhibited significant inhibition against the antibacterial and antifungal strains except Gramnegative organism, Salmonella typhimurium.

Plant extracts have great potential as antimicrobial compounds against microorganisms. Thus, they can be used in the treatment of infectious diseases caused by resistant microbes. From the present study, it is suggested that the methanol extract of Oxystelma esculentum has significant inhibition in lipid peroxidation and possesses good antimicrobial activity in vitro.

\section{ACKNOWLEDGEMENTS}

One of the authors D. Ashokkumar is grateful to
AICTE, New Delhi, India, for providing the financial support to this research work.

\section{REFERENCES}

Ananrthanarayanan R, Jayaram Paniker CK. (1987). Textbook of Microbiology, pp. 39-40, Orient Longman Limited, Madras.

Bartner A, Pfeiffer KP, Batner H. (1994) Applicability of disc diffusion methods required by the pharmacopoeias for testing antibacterial activity of natural compounds. Pharmazie. 49, 512-516.

Chopra RN, Chopra IC, Handa KL, Kapur LD. (1958) Indigenous Drugs of India. Second Edn. p. 598, U.N. Dhur \& Sons Private Limited, Calcutta.

Chopra RN, Nayar SL, Chopra IC. (1956) Glossary of Indian Medicinal Plants, p. 184, Council of Scientific and Industrial Research, New Delhi.

Cowan MM. (1999) Plant products as antimicrobial agents. Clin. Microbiol. Rev. 12, 564-582.

Gamble JS. (1957) Flora of the Presidency of Madras, Vol. II, p. 586, Botanical survey of India, Calcutta.

Goodman and Gillman. (2001) The Pharmacological Basis of Therapeutics, In: Antimicrobial agents, (William A. Petri, Jr) and Antifungal agents (John E. Bennett), Joel G Hardman, Lee E Limbard, Eds, Tenth Edn, pp.1189-1190, 1298-1299, McGraw-Hill, Medical Publishing Division, Newyork.

Hamed AI, Sheded MG, Shaheen AE, Hamada FA, Pizza C, Piacente S. (2004) Polyhydroxypregnane glycosides from Oxystelma esculentum var. alpini. Phytochemistry 65, 975-980.

Jigna P, Rathish N, Sumitra C. (2005) Preliminary screening of some folklore medicinal plants from western India for potential antimicrobial activity. Indian J. Pharmacol. 37, 408-409.

Kirthikar KR, Basu BD. (1975) Indian Medicinal Plants, Vol III, pp. 1915-1917, Bishen Mahendra Pal Singh, Dehradun.

Kokate CK. (1997) Practical Pharmacognosy, pp.110111, Vallabh Prakashan, Delhi, India.

Nadkarni AK. (1954) Indian Materia Medica, pp. 891892, Popular Prakashan, Bombay, India.

National Committee for Clinical Laboratory Standards. (1997) Performance standards for antimicrobial disk susceptibility test. 6th edn. Wagne. Approved standard. M2-A6. PA: NCCLS. 
Ohkawa H, Onishi Yagi K. (1979) Assay for lipid peroxidation in animal tissue by Thiobarbituric acid reaction. Anal. Bio. Chem. 95, 351-358.

Pelczar MJ, Chan JR, Krieg NR. (1997). Microbiology, Fifth Edn, pp. 137-138, Tata McGraw-Hill Publishing Company Limited, New Delhi.

Plaa GL, Witschi H. (1976) Chemicals, Drugs, and Lipid peroxidation. Anпu. Rev. Pharmacol. Toxicol. 16, 125142.

Srivastava S, Khare A, Khare MP. (1991) A cardenolide tetraglycoside from Oxystelma esculentum. Phytochemistry
30, 301-303.

Tsuchiya H, Sato M, Miyasaki T, Fujiwara S, Tanigaki S, Ohyama M, Tanaka T, Inhuma M. (1996) Comparative study on the antibacterial activity of phytochemical flavanones against methicilin-resistant Staphylococcus aureus. J. Ethnopharmacol. 50, 27-34.

Urzua A, Caroli M, Vazquez L, Mendoza L, Wilkens M, Tojo E. (1998) Antimicrobial study of the resinous exudate and diterpenoids isolated from Eupatorium salvia (Asteraceae). J. Ethnopharmacol. 62, 251-254. 